\title{
EKSPERIMENTASI MODEL PEMBELAJARAN \\ KOOPERATIF TIPE THINK TALK WRITE (TTW) DAN THINK \\ PAIR SHARE (TPS) DENGAN STRATEGI TALKING STICK \\ DITINJAU DARI KECERDASAN MAJEMUK SISWA KELAS VII SMPN KOTA SURAKARTA TAHUN PELAJARAN 2014/2015
}

\begin{abstract}
Arinta Rara Kirana ${ }^{1}$, Tri Atmojo Kusmayadi ${ }^{2}$ Riyadi $^{3}$
${ }^{1,2,3}$ Prodi Magister Pendidikan Matematika, FKIP Universitas Sebelas Maret Surakarta Abstract: The objectives of research were to find out: 1) which one providing better mathematics learning achievement, TTW by using talking stick model, TPS by using talking stick model or classical learning model, 2) which one providing better mathematics learning achievement, linguistic intelligence, mathematics logic intelligence or interpersonal intelligence, 3 ) in each multiple intelligence level, which one providing better mathematics learning achievement, TTW by using talking stick model, TPS by using talking stick model or classical learning model, and 4) in each learning models, which one providing better mathematics learning achievement, linguistic intelligence, mathematicslogic intelligence or interpersonal intelligence. This research used the quasi experimental research method. The design of the research was $3 \times 3$ factorial. The population was the students of the seven class of Junior High School in Surakarta City on academic year 2014/2015. The tecnique of sampling was stratified cluster random sampling. The proposed hypothesis of the research were tested by using the unbalanced two-way analysis of variance.The conclusions of this research were as follows: 1) TTW by using talking stick model provided better mathematics achievement than TPS by using talking stick model and classical learning model. 2) the mathematics logic intelligence students had mathematics achievement better than linguistic intelligence, the mathematics achievement of linguistic intelligence is the same as interpersonal intelligence, and the mathematics logic intelligence students had mathematics achievement better than interpersonal intelligence. 3) in each of multiple intelligence categories, students mathematics learning achievement is in constancy with result of learning models.4) in each learning models, the students mathematics learning achievement is in constancy with result of multiple intelligence categories.

Keywords: TTW, TPS, classical learning, multiple intelligence, talking stick, achievement of learning.
\end{abstract}

\section{PENDAHULUAN}

Pendidikan merupakan aspek yang sangat penting dalam kehidupan manusia karena dengan pendidikan diharapkan mampu membentuk sumber daya manusia yang terampil, kreatif dan inovatif. Oleh karena itu, Indonesia menempatkan pendidikan sebagai salah satu prioritas yang utama. Usaha dalam mencapai tujuan pendidikan di Indonesia merupakan tanggung jawab bersama. Salah satu usaha untuk meningkatkan kualitas pendidikan di Indonesia adalah dengan meningkatkan kualitas dalam pembelajaran matematika. Matematika sebagai salah satu sarana berpikir ilmiah sangat diperlukan untuk menumbuhkembangkan kemampuan berpikir logis, sistematis dan kritis dalam diri siswa. Mengingat betapa pentingnya peranan matematika dalam berbagai aspek kehidupan, maka matematika perlu diberikan di setiap jenjang pendidikan mulai dari tingkat SD sampai dengan SMA. Namun dalam perkembangannya, walaupun 
matematika sudah diberikan pada setiap jenjang pendidikan bukan berarti siswa menguasai matematika dengan baik. Pada kenyataannya matematika bukan dianggap sebagai ilmu yang harus dipahami melainkan ilmu yang sulit untuk dipahami. Hal ini dapat ditunjukkan dengan rata-rata hasil ujian nasional mata pelajaran matematika tahun 2013/2014 (Pamer UN) di Kota Surakarta mengenai daya serap terhadap pokok bahasan himpunan adalah 47,28\% sedangkan daya serap nasional adalah 59,39\%. Berdasarkan data tersebut dapat dilihat bahwa daya serap hasil ujian nasional pada materi himpunan di Kota Surakarta masih rendah jika dibandingkan dengan daya serap pada materi himpunan di tingkat nasional.

Hasil belajar yang kurang maksimal ini dipengaruhi oleh beberapa hal diantaranya adalah belum semua guru mampu memilih pendekatan atau model pembelajaran yang tepat dan sesuai dengan tujuan pembelajaran untuk suatu kompetensi tertentu. Kadang guru sendiri belum menguasai berbagai jenis model pembelajaran yang tepat untuk masing-masing kompetensi. Akibatnya, terdapat kecenderungan guru menggunakan pembelajaran klasikal pada setiap kompetensi yang diajarkan. Pada pembelajaran klasikal, guru masih menjadi sumber utama dalam penyampaian informasi, siswa hanya mendengarkan penjelasan guru, dan siswa cenderung pasif. Oleh karenanya, guru mempunyai tanggung jawab untuk mewujudkan proses pembelajaran yang dapat membantu siswa memperoleh hasil yang optimal. Dalam hal ini, hendaknya guru menggunakan strategi, pendekatan dan model pembelajaran yang lebih banyak melibatkan siswa untuk aktif.

Konza dalam Uno (2011) menyatakan bahwa strategi pembelajaran merupakan kegiatan yang dipilih, yaitu yang dapat memberikan fasilitas atau bantuan kepada peserta didik menuju tercapainya tujuan pembelajaran tertentu. Salah satu strategi pembelajaran yang dapat digunakan adalah strategi pembelajaran talking stick. Strategi pembelajaran talking stick dilakukan dengan bantuan tongkat, siapa yang memegang tongkat wajib menjelaskan kembali apa yang telah dipelajari. Pembelajaran talking stick sangat cocok diterapkan bagi siswa SMP. Selain untuk melatih berbicara, pembelajaran ini akan menciptakan suasana menyenangkan dan membuat siswa aktif.

Banyak model pembelajaran yang dapat dikembangkan oleh guru dalam rangka meningkatkan peran aktif siswa. Salah satu model yang dapat digunakan oleh guru adalah model pembelajaran kooperatif. Zakaria dan Sulfitri (2013) menyatakan "The results showed that there was a significant difference of mean in students mathematics achievement between the cooperative group and the traditional group". Hasil penelitian tersebut menyatakan bahwa ada perbedaan prestasi yang signifikan antara siswa dengan menggunakan pembelajaran kooperatif dengan siswa yang menggunakan pembelajaran 
tradisional. Hal yang serupa juga diungkapkan oleh Ajaja dan Eravwoke (2012) yang mengatakan:

"A significant higher achievement test scores of students in cooperative learning group than those in traditional classroom; a significant higher attitude scores of student in cooperative learning group than those in traditional classroom; a significant higher achievement test scores of all students of varying abilities in cooperative learning group than those in traditional classroom".

Hasil penelitian tersebut menyatakan bahwa pencapaian nilai tes siswa dalam pembelajaran kooperatif lebih tinggi daripada siswa pada kelas tradisional. Hasil penelitian yang serupa oleh Ozsoy dan Yildiz (2004) menyatakan "Cooperative learning method is more effective than traditional teaching methods". Hal ini berarti pembelajaran kooperatif lebih efektif daripada pembelajaran tradisional. Selain itu, penelitian Garfield (1993) menyatakan "The use of cooperative learning activities as a form of active learning to supplement or replace traditional lectures". Hasil penelitian tersebut menyatakan bahwa kegiatan pembelajaran kooperatif dapat membentuk keaktifan siswa untuk atau dapat mengganti pembelajaran tradisional. Selain itu, pembelajaran kooperatif juga dapat meningkatkan hasil belajar siswa. Hal ini sejalan dengan hasil penelitian Keeler dan Steinhorst (1995) yang menyatakan bahwa "Student attitudes toward the cooperative group experience were positive“. Hasil penelitian tersebut menyatakan bahwa sikap siswa terhadap pembelajaran kooperatif adalah positif. Giraud (1997) menyatakan "Students in the cooperative learning class achieved higher test scores" yang artinya siswa yang mengikuti pembelajaran dengan model kooperatif memperoleh skor yang lebih tinggi.

Dari hasil penelitian tersebut peneliti mencoba menerapkan model pembelajaran kooperatif untuk memperbaiki pembelajaran guru di kelas. Peneliti memfokuskan penelitian pada model kooperatif tipe TTW (Think Talk Write) dan model kooperatif tipe TPS (Think Pair Share).

Model pembelajaran kooperatif tipe TTW yang diperkenalkan oleh Huinker \& Laughl ini pada dasarnya dibangun melalui berpikir, berbicara, dan menulis. Model ini dikembangkan dari keterlibatan siswa dari proses berpikir setelah membaca, selanjutnya berbicara dan membagi ide dengan teman lain atau dalam kelompok kemudian mengungkapkan dalam tulisan atau rangkuman sesuai dengan kreativitasnya. Dengan strategi pembelajaran ini diharapkan siswa lebih aktif, baik secara individual maupun dalam kelompok belajar. Selain itu, guru dapat memodifikasi model pembelajaran kooperatif tipe TTW dengan pendekatan saintifik. Pada model pembelajaran kooperatif tipe TTW dengan pendekatan saintifik, sebelum mulai tahap think guru dapat memberi gambaran pada siswa mengenai kehidupan nyata dengan materi yang akan dipelajari. 
Dengan adanya inovasi guru tersebut, diharapkan siswa lebih mudah dalam memahami materi dan dapat memperoleh prestasi belajar yang lebih baik.

Model pembelajaran kooperatif tipe TPS adalah pembelajaran kooperatif yang diawali dengan guru mengajukan pertanyaan atau materi pelajaran untuk dipikirkan siswa secara individu. Selanjutnya guru meminta siswa berkelompok untuk berdiskusi, kemudian hasil diskusi antar kelompok dipresentasikan di depan kelas, sharing dengan kelompok lainnya. Guru berperan sebagai fasilitator yang mengarahkan dan memotivasi siswa untuk belajar serta menumbuhkembangkan rasa tanggung jawab siswa sehingga mampu dan aktif memahami persoalan yang dipelajari. Penerapan model pembelajaran TPS memiliki prosedur yang ditetapkan untuk memberi siswa waktu agar berpikir, menjawab dan saling membantu satu sama lain. Model ini didasarkan pada kebersamaan melalui proses kerja sama siswa dalam usaha pendalaman materi pelajaran.

Selain pendekatan dan model pembelajaran yang dilakukan guru belum sesuai, masih ada faktor lain yang dapat mempengaruhi prestasi belajar siswa, salah satunya adalah kecerdasan siswa. Gardner menyatakan bahwa terdapat delapan tipe kecerdasan yang dimiliki setiap orang, yang selanjutnya disebut sebagai kecerdasan majemuk (multiple intelligences), namun tipe dan kadarnya berbeda-beda. Demi memaksimalkan kecerdasan yang dimiliki siswa dengan keterbatasan model dan pendekatan yang digunakan, pada penelitian ini hanya ditinjau pada siswa yang memiliki kecerdasan linguistik, matematis logis, dan interpersonal. Hal tersebut karena kecerdasan linguistik, kecerdasan matematis logis, dan kecerdasan interpersonal lebih dominan kaitannya dengan model pembelajaran dan materi pelajaran yang akan digunakan oleh peneliti. Hal ini sejalan dengan pendapat Bas dan Beyhan (2010) yang menyatakan "While people with a strong logical/mathematical intelligence might respond well to a complex grammar explanation. Other students who have a strong interpersonal intelligence may require a more interactive climate if their learning is to be effective". Berdasarkan hasil penelitian tersebut disebutkan bahwa sebagian besar siswa memiliki kecerdasan matematis logis akan merespon penjelasan bahasa dengan baik, dan siswa yang memiliki kecerdasan interpersonal yang kuat mungkin akan melakukan interaksi yang lebih sehingga pembelajaran mereka akan lebih efektif. Dari penjabaran di atas setiap siswa dapat mempelajari matematika dengan variasi kecerdasan yang berbeda-beda, walaupun matematika dibangun atas dasar pemikiran logis yang lebih banyak melibatkan kecerdasan matematis logis, tetapi juga ada kecerdasan lain yang dominan dalam pembelajaran matematika diantaranya kecerdasan bahasa/linguistik dan kecerdasan interpersonal. Siswa yang gemar membaca dan mengolah kata cenderung memiliki kecerdasan linguistik, siswa yang suka bekerja dengan angka cenderung memiliki 
kecerdasan matematis logis, dan siswa yang suka bekerja secara kelompok cenderung memiliki kecerdasan interpersonal.

Tujuan dari penelitian ini adalah untuk mengetahui: 1) model pembelajaran mana yang memberikan prestasi belajar lebih baik diantara model pembelajaran kooperatif tipe TTW dengan strategi talking stick, tipe TPS dengan strategi talking stick dan model pembelajaran klasikal, 2) Siswa dengan kategori kecerdasan majemuk mana yang mempunyai prestasi belajar lebih baik diantara siswa dengan kecerdasan linguistik, siswa dengan kecerdasan matematis logis atau siswa dengan kecerdasan interpersonal, 3) pada masing-masing kategori kecerdasan majemuk siswa, model pembelajaran mana yang memberikan prestasi belajar lebih baik diantara model pembelajaran kooperatif tipeTTW dengan strategi talking stick, tipe TPS dengan strategi talking stick atau model pembelajaran klasikal, dan 4) pada masing-masing model pembelajaran mana yang mempunyai prestasi belajar yang lebih baik diantara siswa dengan kecerdasan linguistik, siswa dengan kecerdasan matematis logis atau siswa dengan kecerdasan interpersonal.

\section{METODE PENELITIAN}

Berdasarkan permasalahan yang diteliti, jenis penelitian yang digunakan pada penelitian ini adalah penelitian eksperimental semu dengan desain faktorial $3 \times 3$ yang disajikan dalam Tabel 1.

Tabel 1. Rancangan Penelitian

\begin{tabular}{lccc}
\hline \multirow{2}{*}{ Model Pembelajaran } & \multicolumn{3}{c}{ Kecerdasan Majemuk } \\
\cline { 2 - 4 } & $\begin{array}{c}\text { Linguistik } \\
\left(b_{1}\right)\end{array}$ & $\begin{array}{c}\text { Matematis logis } \\
\left(b_{2}\right)\end{array}$ & Interpersonal $\left(b_{3}\right)$ \\
\hline TTW talking stick $\left(a_{1}\right)$ & $(a b)_{11}$ & $(a b)_{12}$ & $(a b)_{13}$ \\
TPS talking stick $\left(a_{2}\right)$ & $(a b)_{21}$ & $(a b)_{22}$ & $(a b)_{23}$ \\
Klasikal $\left(a_{3}\right)$ & $(a b)_{31}$ & $(a b)_{32}$ & $(a b)_{33}$ \\
\hline
\end{tabular}

Populasi dalam penelitian ini adalah seluruh siswa SMP Negeri di Kota

Surakarta. Pengambilan sampel dalam penelitian ini dilakukan dengan cara stratified cluster random sampling. Setelah dilakukan sampling diperoleh SMPN 3 Surakarta mewakili kelompok tinggi, SMPN 14 Surakarta mewakili kelompok sedang dan SMPN 26 Surakarta mewakili kelompok rendah.

Terdapat dua variabel dalam penelitian ini yaitu variabel bebas yang terdiri dari model pembelajaran dan Kecerdasan Majemuk siswa dan variabel terikat yaitu prestasi belajar matematika siswa. Untuk mengumpulkan data digunakan metode tes, metode angket dan metode dokumentasi. Metode tes digunakan untuk mengevaluasi hasil belajar siswa setelah proses pembelajaran untuk mendapatkan prestasi belajar matematika siswa, metode angket digunakan untuk mengetahui Kecerdasan Majemuk siswa yakni linguistik, 
matematis logis, atau interpersonal, sedangkan metode dokumentasi digunakan untuk mengetahui kemampuan awal siswa yang diambil dari nilai ujian nasioal tahun pelajaran 2013/2014.

Teknik analisis data yang digunakan dalam penelitian ini adalah analisis variansi dua jalan dengan sel tak sama dengan desain penelitian $3 \times 3$. Sebelum masing-masing kelompok diberikan perlakuan, terlebih dahulu dilakukan uji prasyarat terhadap data kemampuan awal siswa meliputi uji normalitas dengan menggunakan uji Lilliefors dan uji homogenitas dengan menggunakan uji Bartlet, kemudian dilakukan uji keseimbangan dengan analisis variansi satu jalan dengan sel tak sama untuk mengetahui pupolasi mempunyai kemampuan awal yang sama atau tidak.

\section{HASIL PENELITIAN DAN PEMBAHASAN}

Setelah dilakukan uji normalitas diperoleh sampel berasal dari populasi yang berdistribusi normal, pada uji homogenitas diperoleh bahwa sampel berasal dari populasi yang homogen. Setelah uji normalitas dan homogenitas dilakukan uji keseimbangan dan diperoleh bahwa sampel kelompok eksperimen 1, sampel kelompok eksperimen 2 dan sampel kelompok kontrol berasal dari populasi yang seimbang atau mempunyai kemampuan awal sama. Selanjutnya dilakukan uji hipotesis penelitian. Rerata masingmasing sel dan rerata marginal ditunjukkan pada Tabel 2.

\section{Tabel 2. Rerata Masing-Masing Sel dan Rerata Marginal}

\begin{tabular}{|c|c|c|c|c|}
\hline \multirow{2}{*}{$\begin{array}{c}\text { Model } \\
\text { Pembelajaran }\end{array}$} & \multicolumn{3}{|c|}{ Kategori Kecerdasan Majemuk } & \multirow{2}{*}{$\begin{array}{c}\text { Rerata } \\
\text { Marginal }\end{array}$} \\
\hline & Linguistik & Matematis logis & Interpersonal & \\
\hline TTW talking stick & 70,19 & 87,43 & 71,29 & 76,30 \\
\hline TPS talking stick & 58,24 & 77,05 & 60,13 & 65,14 \\
\hline Klasikal & 56,63 & 76,67 & 59,46 & 64,25 \\
\hline Rerata Marginal & 61,69 & 80,38 & 63,62 & 68,56 \\
\hline
\end{tabular}

Tabel 3. Rangkuman Analisis Variansi Dua Jalan dengan Sel Tak Sama

\begin{tabular}{|c|c|c|c|c|c|c|}
\hline Sumber & $\mathrm{dk}$ & $\mathrm{JK}$ & RK & $F_{o b s}$ & $F_{t a b}$ & Keputusan \\
\hline $\mathrm{A}$ & 2 & 7747,1733 & 3873,5867 & 31,5967 & 3,00 & $H_{0 A}$ ditolak \\
\hline $\mathrm{B}$ & 2 & 18149,5447 & 9074,7723 & 74,0226 & 3,00 & $H_{0 B}$ ditolak \\
\hline $\mathrm{AB}$ & 4 & 57,3755 & 14,3439 & 0,1170 & 2,37 & $H_{O A B}$ diterima \\
\hline Galat & 275 & 33713,5256 & 122,5946 & - & - & - \\
\hline Total & 283 & 59667,6191 & - & - & - & - \\
\hline
\end{tabular}

berpengaruh terhadap prestasi belajar matematika siswa, (b) Kecerdasan Majemuk berpengaruh terhadap prestasi belajar matematika siswa, (c) tidak terdapat interaksi antara model pembelajaran dan Kecerdasan Majemuk siswa. 
Berdasarkan hasil perhitungan Anava diperoleh $H_{0 A}$ ditolak. Berarti tidak semua model pembelajaran memberikan pengaruh yang sama terhadap prestasi belajar matematika siswa, maka perlu dilakukan uji Scheffe. Perhitungan uji lanjut anava rerata antar baris ditunjukkan pada Tabel 4.

Tabel 4. Hasil Uji komparasai Rerata Antar Baris

\begin{tabular}{cccc}
\hline Ho & $F_{\text {hit }}$ & $2 F_{0,05 ; 2,275}$ & KeputusanUji \\
\hline$\mu_{1 .}=\mu_{2 .}$ & 108,1562 & 6,00 & $H_{0}$ ditolak \\
$\mu_{1 .}=\mu_{3 .}$ & 143,7484 & 6,00 & $H_{0}$ ditolak \\
$\mu_{2 .}=\mu_{3 .}$ & 2,4272 & 6,00 & $H_{0}$ diterima \\
\hline
\end{tabular}

Dari Tabel 4 dan dengan memperhatikan Tabel 2 diperoleh (a) model pembelajaran TTW dengan strategi talking stick lebih baik daripada model pembelajaran TPS dengan strategi talking stick terhadap prestasi belajar matematika siswa, (b) model pembelajaran kooperatif tipe TTW dengan strategi talking stick lebih baik daripada model pembelajaran klasikal terhadap prestasi belajar matematika siswa, (c) prestasi belajar matematika dengan model pembelajaran TPS dengan strategi talking stick sama baiknya dengan model pembelajaran klasikal. Hal ini mendukung pendapat Purwanto (2012) yang menyimpulkan bahwa prestasi belajar matematika siswa yang diajar dengan model pembelajaran kooperatif tipe TTW lebih baik daripada yang diajar dengan pembelajaran kooperatif tipe TPS.

Dari hasil perhungan anava diperoleh $H_{0 B}$ ditolak berarti tidak semua kecerdasan majemuk memberikan pengaruh yang sama terhadap prestasi belajar matematika siswa, maka perlu dilakukan uji lanjut Anava dengan metode Scheffe. Perhitungan uji lanjut anava rerata antar kolom ditunjukkan pada Tabel 5.

\section{Tabel 5. Hasil Uji komparasai Rerata Antar Kolom}

\begin{tabular}{lccc}
\hline$H o$ & $F_{\text {hit }}$ & $2 F_{0,05 ; 2,275}$ & KeputusanUji \\
\hline$\mu_{-1}=\mu_{-2}$ & 151,5851 & 6,00 & $H_{0}$ ditolak \\
$\mu_{-1}=\mu_{-3}$ & 0,4084 & 6,00 & $H_{0}$ diterima \\
$\mu_{-2}=\mu_{-3}$ & 138,7276 & 6,00 & $H_{0}$ ditolak \\
\hline
\end{tabular}

Dari Tabel 5 dan dengan memperhatikan Tabel 2 diperoleh (a) prestasi belajar matematika pada siswa dengan tipe kecerdasan matematis logis lebih baik daripada pestasi belajar matematika siswa dengan tipe kecerdasan linguistik, (b) prestasi belajar matematika siswa dengan tipe kecerdsana linguistik sama baiknya dengan prestasi belajar matematika siswa dengan tipe kecerdasan interpersonal, (c) prestasi belajar matematika pada siswa dengan tipe kecerdasan matematis logis lebih baik daripada pestasi belajar matematika siswa dengan tipe kecerdasan interpersonal. Hasil penelitian tersebut sejalan dengan penelitian Heni (2011) yang disimpulkan tidak ada perbedaan prestasi belajar matematika antara siswa yang mempunyai tipe kecerdasan linguistik dan siswa yang mempunyai tipe kecerdasan interpersonal dan hasil Hidayatus (2014) yang 
menyimpulkan prestasi belajar matematika siswa dengan kecerdasan matematis logis lebih baik daripada kecerdasan interpersonal dan linguistik.

Dari perhitungan anava diperoleh $H_{0 A B}$ tidak ditolak, maka tidak terdapat interaksi antara model pembelajaran dengan kecerdasan majemuk siswa, sehingga tidak perlu dilakukan uji lanjut anava antar sel. Untuk tiap-tiap model pembelajaran, kesimpulan dapat diambil dari karakteristik efek utama antar kolom, maka siswa dengan kecerdasan matematis logis memiliki prestasi yang lebih baik daripada siswa dengan kecerdasan linguistik, siswa dengan kecerdasan linguistik memiliki prestasi yang sama baik dengan siswa dengan kecerdasan interpersonal, dan siswa dengan kecerdasan matematis logis memiliki prestasi yang lebih baik daripada siswa dengan kecerdasan interpersonal. Untuk masing-masing kecerdasan majemuk, kesimpulannya dapat diambil dari karakteristik efek utama antar baris, maka model pembelajaran kooperatif tipe TTW dengan strategi talking stick memberikan prestasi lebih baik daripada model pembelajaran kooperatif tipe TPS dengan strategi talking stick, model pembelajaran kooperatif tipe TTW dengan strategi talking stick menghasilkan prestasi lebih baik daripada model pembelajaran klasikal, dan model pembelajaran kooperatif tipe TPS dengan strategi talking stick menghasilkan prestasi yang sama dengan model pembelajaran klasikal.

\section{SIMPULAN DAN SARAN}

Berdasarkan analisis data dari penelitian yang dilakukan, dapat disimpulkan sebagai berikut: (1) model pembelajaran kooperatif tipe TTW dengan strategi talking stickmemberikan prestasi belajar matematika yang lebih baik daripada model pembelajaran TPS dengan strategi talking stick ataupun pembelajaran klasikal, (2) Prestasi belajar matematika siswa dengan tipe kecerdasan matematis logis lebih baik daripada prestasi belajar matematika siswa dengan tipe kecerdasan linguistik, prestasi belajar matematika siswa dengan tipe kecerdasan linguistik sama dengan prestasi belajar matematika siswa dengan tipe kecerdasan interpersonal, dan prestasi belajar matematika siswa dengan tipe kecerdasan matematis logis lebih baik daripada prestasi belajar matematika dengan tipe kecerdasan interpersonal, (3) Pada masing-masing tipe kecerdasan majemuk yakni linguistik, matematis logis, dan interpersonal, prestasi belajar matematika dengan menggunakan pembelajaran kooperatif tipe TTW dengan strategi talking stick lebih baik daripada menggunakan model pembelajaran kooperatif tipe TPS dengan strategi talking stick, prestasi belajar matematika dengan menggunakan kooperatif tipe TTW dengan strategi talking stick lebih baik daripada model pembelajaran klasikal, sedangkan model pembelajaran kooperatif tipe TPS dengan strategi talking stick memiliki prestasi yang sama dengan model pembelajaran klasikal, (4) Pada masing-masing model 
pembelajaran kooperatif tipe TTW dengan strategi talking stick, TPS dengan strategi talking stick dan pembelajaran klasikal, tipe kecerdasan matematis logis memiliki prestasi yang lebih baik daripada siswa yang mempunyai tipe kecerdasan linguistik, siswa dengan tipe kecerdasan linguistik memiliki prestasi yang sama baik dengan siswa yang mempunyai tipe kecerdasan interpesonal, dan siswa dengan tipe kecerdasan matematis logis memiliki prestasi yang lebih baik daripada siswa yang mempunyai tipe kecerdasan interpersonal.

Adapun saran dari hasil penelitian ini adalah (1) Dalam pembelajaran matematika khususnya pokok bahasan himpunan model pembelajaran kooperatif tipe TTW dengan strategi talking stick dapat dijadikan alternatif dalam pembelajaran matematika agar siswa memperoleh prestasi belajar yang lebih baik; (2) Guru hendaknya memperhatikan faktorfaktor yang mempengaruhi obyektivitas siswa dalam pengisian angket kecerdasan majemuk karena hal ini dapat berpengaruh dalam pengkategorian kecerdasan majemuk siswa menjadi kurang akurat.

\section{DAFTAR PUSTAKA}

Ajaja, O.P. and Eravwoke, O.U.2010. Effects of Cooperative Learning Strategy on Junior Secondary School Students Achievement in Integrated Science. Electronic Journal of Science Education. Vol. 14, No. 1, 1-18.

Bas, G. dan Beyhan, O. 2010. Effects of Multiple Intelligences Supported Project Based Learning on Student's Achievement Levels and Attitudes towards English Lesson. International Electronic Journal of Elementary Education. Vol 2, No 3, 365-386.

Garfield, J. 1993. Teaching Statistics Using Small-Group Cooperative Learning. Journal of Statistics Education. Vol 1, No 1,1-6.

Giraud, G. 1997. Cooperative Learning and Statistics Instruction. Journal of Statistics Education. Vol 5, No 1, 1-9.

Heni, D.M. 2011. Efektivitas model pembelajaran kooperatif tipe stad (student team achievement division) yang dimodifikasi dengan tutor sebaya dalam pembelajaran matematika pada pokok bahasan barisan dan deret aritmetika serta geometri ditinjau dari kecerdasan majemuk siswa. Tesis: Surakarta: Universitas Sebelas Maret.

Hidayatus. 2014. Eksperimentasi Model Pembelajaran Kooperatif Tipe Group Investigation (GI) Dan Numbered Heads Together (NHT) Pada Materi Garis Singgung Lingkaran Ditinjau Dari Kecerdasan Majemuk Siswa. Tesis: Surakarta: Universitas Sebelas Maret.

Keeler, C.M. and Steinhorst, R.K. 1995. Using Small Groups to Promote Active Learning in the Introductory Statistics Course: A Report from the Field. Journal of Statistics Education. Vol 3, No 2, 1-5. 
Ozsoy, N. dan Yildiz, N. 2004. The Effect of Learning Together Technique of Cooperative Learnimg Method on Student Achievement in Mathematics teaching. The Turkish Online Journal of Educational Technology. Vol 3, No 3, 49-54.

Purwanto, B. 2011. Eksperimentasi Model Pembelajaran Kooperatif Tipe TTW dan Tipe TPS pada Materi Statistika Ditinjau dari Kemandirian Belajar Siswa. Tesis: Surakarta: Universitas Sebelas Maret.

Uno, H.B. 2011. Model Pembelajaran : menciptakan proses belajar mengajar yang kreatif dan efektif. Jakarta: Bumi Aksara.

Zakaria, E. dan Sulfitri, T. 2013. Effect of Cooperative Learning on Secondary School Students Mathematics Achievement. Journal of Scientific Research. Vol 4, No 2, 98-100. 